\title{
In vitro Antimicrobial Activity Evaluation of Mangrove Fruit (Sonneratia caseolaris L.) Extract
}

\author{
Islamudin Ahmad ${ }^{1 *}$, Neneng Siti Silfi Ambarwati ${ }^{2}$, Arif Lukman', Muhammad Amir Masruhim ${ }^{3}$, Laode Rijai ${ }^{4}$, \\ Abdul Mun'im ${ }^{5}$
}

\section{Islamudin Ahmad ${ }^{1 *}$, Neneng Siti Silfi Ambarwati ${ }^{2}$, Arif Lukman', Muhammad Amir Masruhim ${ }^{3}$, Laode Rijai ${ }^{4}$, Abdul Mun'im ${ }^{5}$}

'Department of Pharmaceutical Sciences, Faculty of Pharmacy, Mulawarman University, Samarinda, East Kalimanta, 75119, INDONESIA. ${ }^{2}$ Faculty of Engineering, Universitas Negeri Jakarta, East Jakarta, 13220, INDONESIA.

${ }^{3}$ Department of Chemistry Education, Faculty of Teacher Training and Education Sciences, Mulawarman University, Samarinda, East Kalimantan, 75119, INDONESIA.

${ }^{4}$ Pharmaceutical Research and Development Laboratory of FARMAKA TROPIS, Faculty of Pharmacy, Mulawarman University, Samarinda, East Kalimantan, 75119, INDONESIA. ${ }^{5}$ Department of Pharmaceutical Sciences, Faculty of Pharmacy, Universitas Indonesia, Depok, West Java, 16424, INDONESIA

\section{Correspondence}

Islamudin Ahmad

Gedung Administrasi Fakultas Farmasi, Universitas Mulawarman, Jalan Penajam, Kampus UNMUL Gunung Kelua, Samarinda, East Kalimantan, 75119, INDONESIA.

Phone no: +6281342205060

E-mail: islamudinahmad@farmasi.unmul. ac.id

History

- Submission Date: 04-12-2017;

- Review completed: 10-01-2018;

- Accepted Date: 22-01-2018

DOI : 10.5530/pj.2018.3.98

Article Available online

http://www.phcogj.com/v10/i3

Copyright

(C) 2018 Phcog.Net. This is an openaccess article distributed under the terms of the Creative Commons Attribution 4.0 International license.

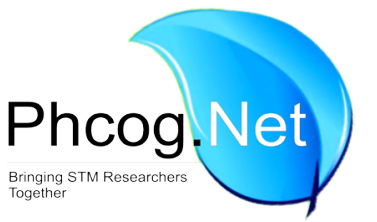

\begin{abstract}
Introduction: Mangrove fruit (Sonneratia caseolaris L) from Sonneratiaceae family known with local name "Pidada Merah" has bioactive components. The present study aimed to evaluate the antimicrobial activity of this plant. Method: The sample was macerated using methanol, the antimicrobial activity assay was performed using agar disc diffusion method against Escherichia coli ATTC9637, Staphylococcus aureus ATTC6538, and Candida albicans ATTC10231. Results: Antimicrobial activity of Mangrove fruit methanol extract were obtained the optimum concentration of S. aureus of $80 \%, E$. coli of $15 \%$, and C. albicans of $30 \%$. Conclusion: based on the results, the sample has antimicrobial properties, and this is a preliminary data for further study.

Key words: Sonneratia caseolaris L, Mangrove fruit, Antimicrobial activity, Agar disc diffusion method.

Key Messages: Evaluation of antimicrobial activity of Mangrove fruit (Sonneratia caseolaris L.) extract against Escherichia coli, Staphylococcus aureus, and Candida albicans using Agar disc diffusion method.
\end{abstract}

\section{INTRODUCTION}

Sonneratia caseolaris L. is one of the plants from Sonneratiaceae family, known as Mangrove with local name "Pidada Merah." This plant is foolproof found in coastal areas and estuaries where other plants difficult to grow. ${ }^{1}$ Several studies have reported that almost all parts of the plant have pharmacological properties, including astringent, antiseptic, ${ }^{2}$ analgesic, antiinflammatory, ${ }^{3}$ antimicrobial, ${ }^{4,5,6}$ antidiabetic, ${ }^{7}$ antioxidant. ${ }^{8,9}$ Also used as a traditional cosmetic by the local community in Kalimantan island, Indonesia (especially Dayak tribe) called "bedak dingin". ${ }^{10}$ This plant contains secondary metabolites such as flavonoids, ${ }^{11}$ phenolics, terpenoids, steroids, and alkaloids. ${ }^{3,12,13}$

S. caseolaris is a plant to bear fruit and includes numerous small seeds are covered with flesh. It has bioactive components including Alkaloids, saponins, terpenoids, tannins, flavonoids, steroids, and derivates of benzene carboxylate, ${ }^{8,12}$ and commonly consumed by the community in Java and Kalimantan island. The ripe fruit has a distinctive flavor and pharmacological properties similar to other parts. On the other hand, the study of bioactive compounds from Mangrove fruit is still limited. The previous research has been reported that the fruit extract has a pharmacological activity as anticolesterol. ${ }^{14}$ and antidiabetic. ${ }^{15}$ The fruit is also non-toxic and safe to consume routinely. ${ }^{12}$ However, research antimicrobial active constituent on Mangrove fruit has not been reported.

Antimicrobial activity assay on Mangrove fruit extract using the gram-negative bacteria of Escherichia coli, the gram-positive bacteria of Staphylococcus aureus, and the yeast of Candida albicans conducted with agar disc diffusion method. This study aimed to explore as antimicrobial properties, in particular against potential human pathogens.

\section{SUBJECTS AND METHODS}

\section{Plant Material}

A sample of Mangrove fruit (S. caseolaris) was collected from Muara Badak, Kutai Kertanegara, East Kalimantan, Indonesia, and was identified at Laboratory of Dendrology, Faculty of Forestry, Mulawarman University, Samarinda, East Kalimantan, Indonesia. The specimen was deposited at Pharmaceutical Research and Development Laboratory of FARMAKA TROPIS, Faculty of Pharmacy, Mulawarman University.

\section{Materials and General Equipment}

The chemical material was used including chloramphenicol, metronidazole, Nutrient Agar (NA) and Potato Dextrose Agar (PDA) were purchased from Sigma-Aldrich, Germany. Staphylococcus aureus ATTC6538 (S. aureus), Escherichia coli ATTC9637 (E. coli), and Candida albicans ATTC10231 (C. albicans) were purchased from Sigma-Aldrich, Germany.

Cite this article: Ahmad I, Ambarwati NSS, Lukman A, Masruhim MA, Rijai L, Mun'im A. In vitro Antimicrobial Activity Evaluation of Mangrove Fruit (Sonneratia caseolaris L.) Extract. Pharmacog J. 2018;10(3):598-601. 
Aqua demineralization (Agua $\mathrm{DM}$ ), methanol, and $\mathrm{NaCl} 0.9 \%$ dilution were obtained from PT SmartLab Indonesia, Indonesia. The equipment was utilized, such us rotary evaporator (Stuart), Waterbath (Wisebath), autoclave (Tomy SX-700), Oven (Mammet), incubator (Mammet), Petri Dishes (Normax), Laminar Air Flow (LAF) (Nuarie NU-126-400 E), Vernier calipers, and maceration equipment.

\section{Extraction Process}

The extraction process performed using a conventional method based on some the literature, ${ }^{16,17,18}$ with slight modification. Briefly, the dried fruit ( $420 \mathrm{~g}$ ) was macerated (three times) using $2 \mathrm{~L}$ methanol for $24 \mathrm{~h}$ and was filtered to separate the extract solution and residue. The extract solution was evaporated to got dry extract. The extract was dry-stored $(44.15 \mathrm{~g})$ in sterile Eppendorf at a cold temperature until further used.

\section{Antimicrobial Assay}

An antimicrobial test using Agar disc diffusion method ${ }^{4,17,19,20}$ against E. coli, S. aureus, and C. albicans. Briefly, The bacterial and yeast suspension were diluted at 1:40 and 1:20, respectively. The dilution suspension of $0.02 \mathrm{~mL}$ was mixed with $10 \mathrm{ml}$ of medium NA and PDA in Petri, homogenized, and waited to form the semi-solid medium. The Paper discs (with a diameter of $6 \mathrm{~mm}$, Whatman) were dipped into the test solution extracts and silenced for a moment, then laid on the surface of the solid medium NA and PDA, and incubated at $37^{\circ} \mathrm{C}$ for $24 \mathrm{~h}$. The negative control using distilled water, whereas the positive control using chloramphenicol (antibacterial) and metronidazole (antifungal). The antimicrobial activity was calculated by the area of total/partial inhibition zone.

\section{RESULTS}

Antimicrobials are compounds that used to inhibit or kill microbial growth. Microbes were employed in this study including gram-positive bacteria of $S$. aureus, gram-negative bacteria of E. coli, and the yeast of C. albicans using agar disc diffusion method. The antimicrobial activity of fruit extracts Mangrove indicated by their inhibition zone which is an area of bright or turbid influenced by the extracts that are not covered by the microbes. Further zones are measured in diameter are formed by using a micrometer screw.

The concentration of fruit extracts mangrove was utilized in this study include S. aureus $(60 \%, 70 \%, 80 \%$ and $90 \%)$, E. coli $(5 \%, 10 \%, 15 \%$ and $20 \%$ ), and $0.025 \%$ chloramphenicol a positive control. Whereas C. albicans was used at $20 \%, 25 \%, 30 \%$ and $35 \%$, and $0.15 \%$ metronidazole as a positive control (can be seen in Figure 1).

As can be seen in Figure 2, showed the antimicrobial activity of Mangrove fruit extract against the bacteria of $E$. coli, which was characterized by the total/partial inhibition zone around the paper disc. The highest total/ partial inhibition zone was at a concentration of $15 \%$, while at $20 \%$ has decreased.

In Figure 3 demonstrated the antimicrobial activity of mangrove fruit extracts against $S$. aureus which was characterized by the partial inhibition zone at a concentration from $10 \%$ to $50 \%$ and the total inhibition zone at a level from $60 \%$ to $90 \%$. The highest and optimum the total inhibition zone was at $80 \%$.

The antimicrobial activity of Mangrove fruit extract to C. albicans yeast presented in Figure 4 and marked by the total inhibition zone around the paper disc. The highest and optimum of antimicrobial activity was demonstrated at $30 \%$.

\section{DISCUSSION}

Differences in the ability of the Mangrove fruit extract in providing antimicrobial activity based on the difference of the cell wall structure, where the yeast has no cell wall, while opposite in the bacteria. In the
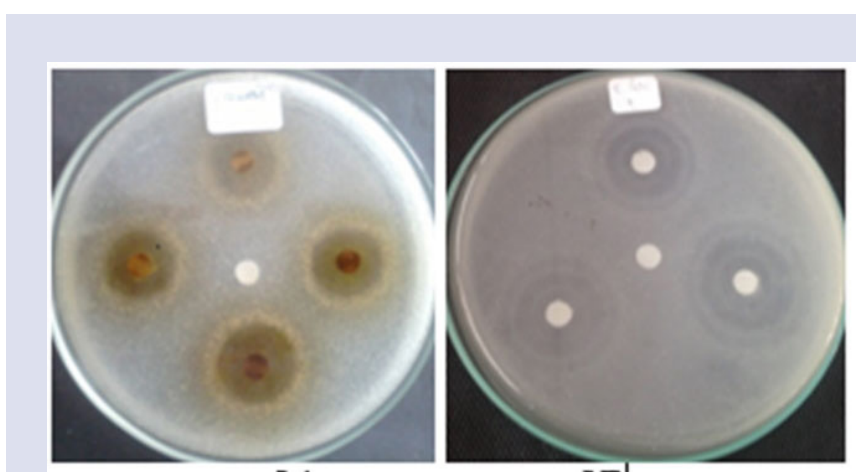

lA

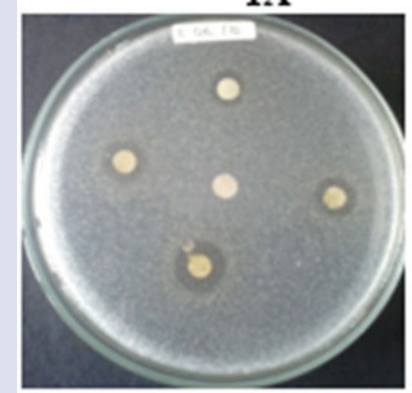

$2 \mathrm{~A}$

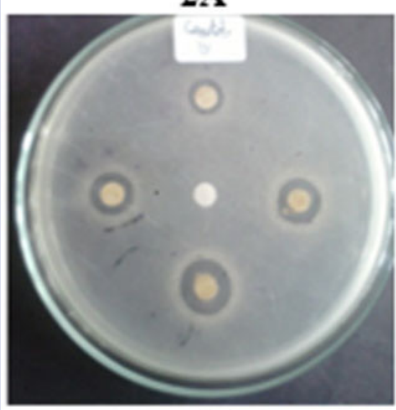

$3 \mathrm{~A}$

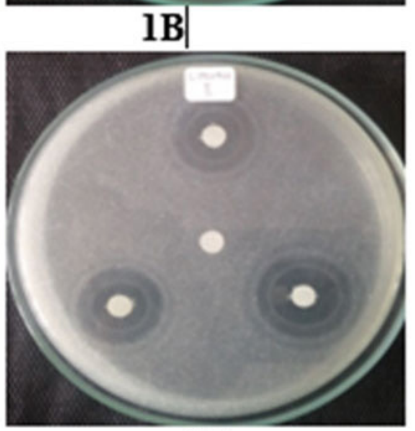

2B

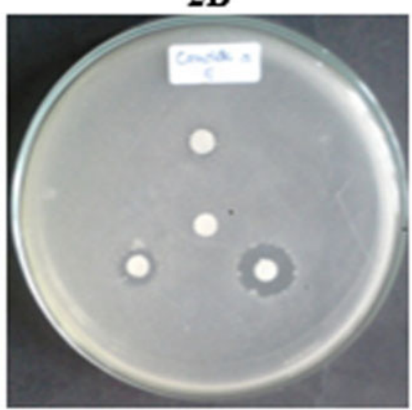

3B
Figure 1: Antimicrobial activity test of Mangrove fruit extract $(A)$ and positive control (B) against (1) E. coli, (2) S. aureus, and (3) C. albicans.

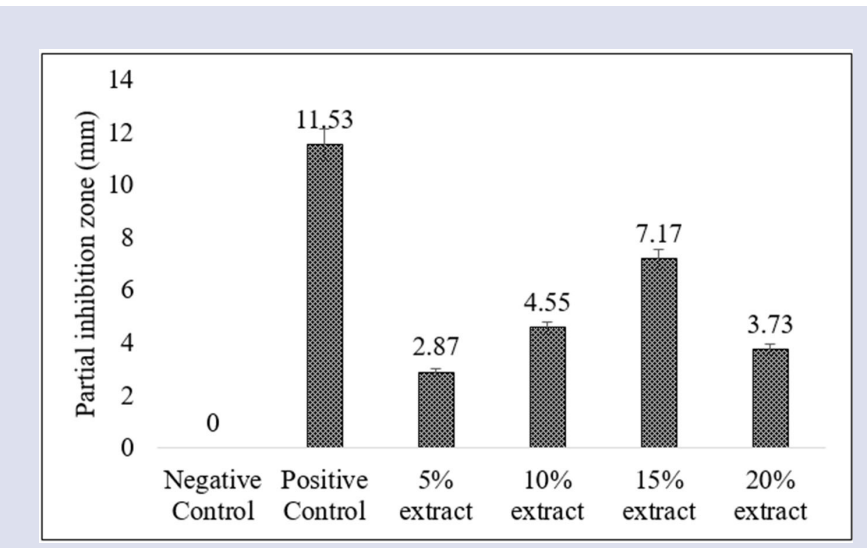

Figure 2: Antimicrobial activity of Mangrove fruit extract against E. coli. 


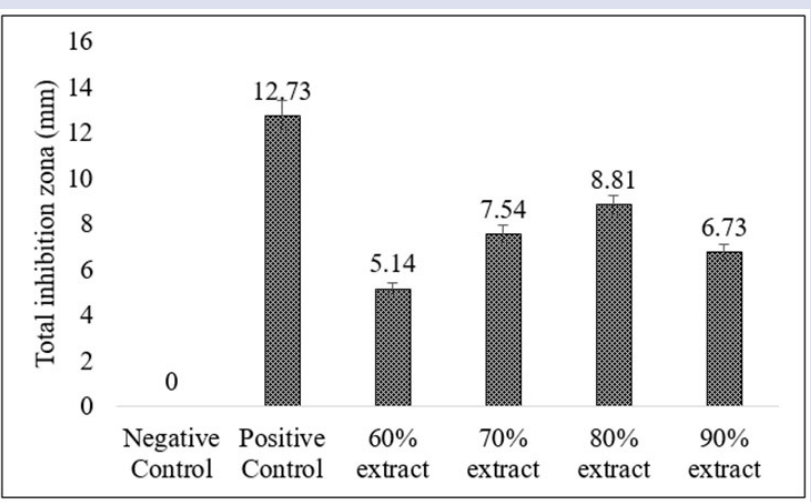

Figure 3: Antimicrobial activity of Mangrove fruit extract on S. aureus.

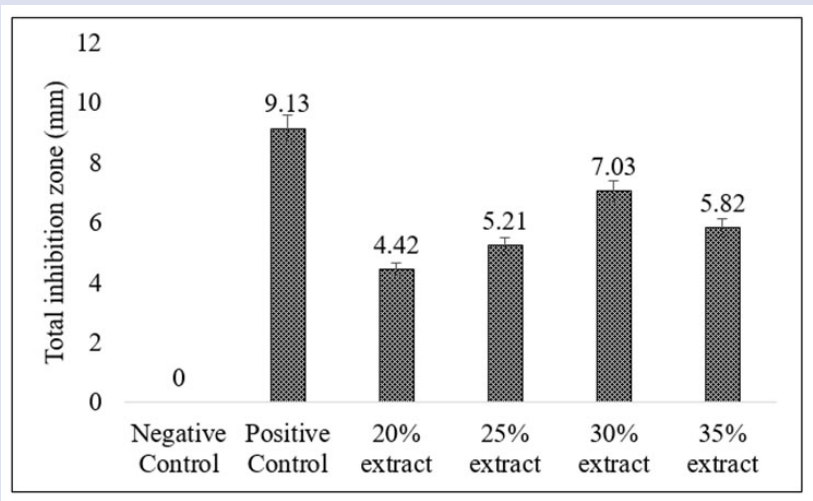

Figure 4: Antimicrobial activity of Mangrove fruit extract against C. albicans.

bacteria requires a high concentration compared to the yeast in providing the inhibition zone, where the cell wall of bacteria consists peptidoglycan which serves as additional protection from external influences. Also, it also helps to prevent rupture of the cells by osmotic pressure on the hypotonic environment. The cell walls of gram-positive bacteria are composed of a single layer of relatively thicker peptidoglycan, while the gram-negative bacteria consisting of two layers, namely the outer layer (contains lipopolysaccharide and protein) and the inner layer including the thin peptidoglycan. Also, differences in the ability of Mangrove fruit extracts inhibit or kill the growth of microbes may be caused by sensitivity to antimicrobial compounds contained in extracts, wherein the constituent is more sensitive to the yeast and the gram-negative bacteria compared to the gram-positive bacteria. Microbial growth influenced by several factors include (1) the osmotic pressure difference inside and outside the cell, (2) the cell membrane damage due to irritation, (3) changes in $\mathrm{pH}$, and (4) the cell fluid diffusion. ${ }^{17,19-22}$

The decreased power of inhibition zone at the highest concentration of the possibility because of the rate of diffusion of active substances. In general, the diameter of inhibition zone tends to increase proportionately to the increasing level of the extract but does not occur in this extract. It is due to the growing concentration of the extract also enhance the viscosity of a sample which affects the absorption of the extract through the paper disc and diffusion of the extract on medium.

\section{CONCLUSION}

Based on the above results, the mangrove fruit extracts have antimicrobial activity; mainly the compound is more sensitive to C. albicans and $S$. aureus compared to E. coli. The results of this study are preliminary data, and further research focused on the identification and isolation of compounds responsible as an antimicrobial.

\section{ACKNOWLEDGEMENT}

Authors are grateful to Dean Faculty of Pharmacy and Head Laboratory of Pharmaceutical Research and Development FARMAKA TROPIS, Faculty of Pharmacy, Mulawarman University for their support and the facility in this study.

\section{CONFLICT OF INTEREST}

We declared that we have no conflict of interest

\section{ABBREVIATONS USED}

S. caseolaris; Sonneratia caseolaris L, NA; nutrient agar, PDA; potato dextrose agar, LAF; laminar air flow, S. aureus; Staphylococcus aureus ATTC6538, E. coli; Escherichia coli ATTC9637, C. albicans; Candida albicans ATTC10231, ${ }^{\circ} \mathrm{C}$; degree Celsius

\section{REFERENCES}

1. Rani PU, Sandhyarani K, Vadlapudi V, Sreedhar B. Bioefficacy of a mangrove plant, Sonneratia caseolaris and a mangrove associate plant, Hibiscus tiliaceus against certain agricultural and stored product pests. J Biopest. 2015;8(2):98-106.

2. Ghani A. Medicinal Plants of Bangladesh with Chemical Constituents and Uses. Second Edi. Dhaka: Asiatic Society of Bangladesh; 1998.

3. Bandaranayake W. Bioactive compounds and chemical constituent of Mangrove plants. Wetl Ecol Manag. 2002;10(6):421-52

4. Buatong J, Phongpaichit S, Rukachaisirikul V, Sakayaroj J. Antimicrobial activity of crude extracts from mangrove fungal endophytes. World J Microbiol Biotechnol. $2011 ; 27(12): 3005-8$

5. Tian M, Dai H, Li X, Wang B. Chemical constituents of marine medicinal mangrove plant Sonneratia caseolaris. Chinese J Oceanol Limnol. 2009;27(2):288-96.

6. Simlai A, Rai A, Mishra S, Mukherjee K, Roy A. Antimicrobial and antioxidative activities in the bark extracts of Sonneratia caseolaris, A mangrove plant. Excli J. 2014;13:997-1010

7. Das SK, Samantaray D, Patra JK, Samanta L, Thatoi H. Antidiabetic potential of mangrove plants: a review. Front Life Sci. 2016;9(1):75-88.

8. Varghese J, Belzik N, Nisha A, Remi S, Silvipriya K. Pharmacognostical and phytochemical studies of a mangrove (Sonneratia caseolaris L.) from Kochi of Kerala State in India. J Pharm Res. 2010;3(11):2625-7.

9. Bunyapraphatsara N, Jutiviboonsuk A, Sornlek P, Therathanathorn W, Aksornkaew S, Fong HHS, et al. Pharmacological studies of plants in the mangrove forest. Thai J Phytopharm. 2003;10(2):1-2.

10. Arung ET, Kuspradini H, Kusuma IW, Bang TH, Yamashita S, Katakura Y, et al. Effects of the isolated compound from Sonneratia caseolaris leaf: A validation of traditional utilization by melanin biosynthesis and antioxidant assays. J Appl Pharm Sci. 2015;5(10):39-43.

11. Sadhu S, Ahmed F, Ohtsuki T, Ishibashi M. Flavonoids from Sonneratia caseolaris. J Nat Med. 2006;60(3):264-5.

12. Jariyah, Widjanarko SB, Yunianta, Estiasih T. Phytochemical and acute toxicity studies of ethanol extract from Pedada (Sonneratia caseolaris) fruit flour (PFF). Int Journal Adv Sci Eng Inf Technol. 2015;5(2):95-8

13. Jariyah, Azkiyah L, Widjanarko S, Estiasih T, Yuwono S, Yunianta. Hypocholesterolemic effect of Pedada (Sonneratia caseolaris) fruit flour in Wistar Rats. Int J Pharm Tech Res. 2013;5(4):1619-27.

14. Simlai A, Roy A. Biological activities and chemical constituents of some mangrove species from Sundarban estuary: An overview. Phcog Rev. 2013;7:170-8

15. Jariyah, Widjanarko S, Estiasih T, Yunianta. Hyglycemic effect of Pedada (Sonneratia caseolaris) fruit flour (PFF) in Alloxan-Induced diabetic Rats. Int J PharmTech Res. 2014;7(1):31-40.

16. Ahmad I, Yanuar A, Mulia K, Mun'im A. Application of ionic liquid based microwave-assisted extraction of the secondary metabolite from Peperomia pellucida (L) Kunth. Pharmacogn J. 2017;9(2):227-34. doi:10.5530/pj.2017.2.38.

17. Shamsuddin AA, Najiah M, Suvik A, Azariyah MN, Kamaruzzaman BY, Effendy AW, et al. Antibacterial properties of selected mangrove plants against Vibrio species and its cytotoxicity against Artemia salina. World Appl Sci J. 
2013;25(2):333-40

18. Ahmad I, Sulistiarini R, Rijai L. Antioxidant activity of some selected East Borneo plants. Int J Public Health Sci. 2015;4(1):58-62.

19. Kaewpiboon C, Lirdprapamongkol K, Srisomsap C, Winayanutattikun $P_{\text {, }}$ Yongvanich T, Puwaprisirisan $\mathrm{P}$, et al. Studies of the in vitro cytotoxic, antioxidant, lipase inhibitory and antimicrobial activities of selected Thai medicinal plants. BMC Complement Altern Med. 2012;12(1):217.

20. Ambawati NSS, Elya B, Malik A, Hanafi M. Evaluation of antimicrobial activities of Garcinia latissima Miq. stem bark extract. JYoung Pharm. 2017;9(1):118-21.

21. Nag M, Mukherjee PK, Biswas R, Chanda J, Kar A. Evaluation of antimicrobial potential of some Indian Ayurvedic medicinal plants. Pharmacogn J. 2016;8(6):525-33.

22. Soliman S, Alnajdy D, El-Keblawy AA, Mosa KA, Khoder G, Noreddin AM Plants' natural products as alternative promising anti-Candida drugs. Phcog Rev. 2017; $11(22): 104-22$

GRAPHICAL ABSTRACT

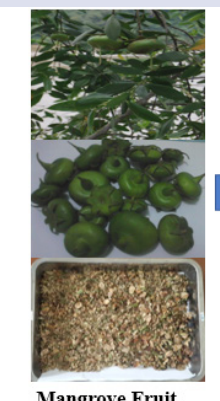

Mangrove Fruit

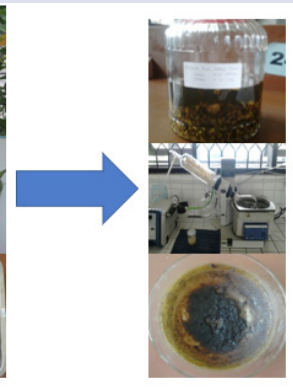

Extraction Process

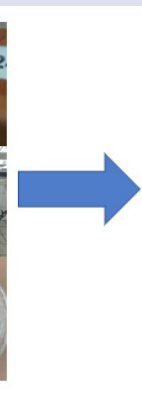

In vitro antimicrobial assay

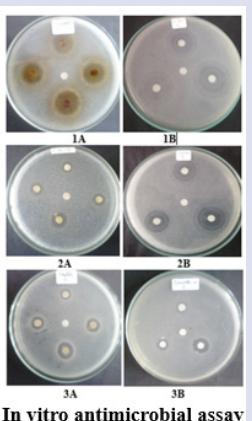

\section{SUMMARY}

- Mangrove fruit (Sonneratia caseolaris L) from Sonneratiaceae family known with local name "Pidada Merah".

- Antimicrobial activity of Mangrove fruit methanol extract were obtained the optimum concentration of S. aureus of $80 \%$, E. coli of $15 \%$, and C. albicans of $30 \%$.

- Mangrove fruit (Sonneratia caseolaris L) has antimicrobial properties and this is a preliminary data for further study.

\section{ABOUT AUTHORS}

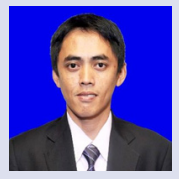

Islamudin Ahmad: A Doctor Candidate at Department of Pharmaceutical Sciences, Faculty of Pharmacy, Universitas Indonesia (UI), Depok, West Java, Indonesia. He is a lecturer at Faculty of Pharmacy, Mulawarman University, Samarinda, East Kalimantan, Indonesia. The doctoral research focused on the study of extraction engineering, screening activity and angiotensin converting enzyme (ACE) inhibitory active compound from the natural product for drugs discovery as antihypertension

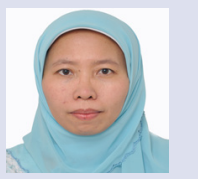

Neneng Siti Silf Ambarwati: A Doctor Candidate at Department of Pharmaceutical Sciences, Faculty of Pharmacy, Universitas Indonesia, Depok, West Java, Indonesia. She is a lecturer at Department of Health and Beauty, Faculty of Engineering, Jakarta State University, Jakarta, Indonesia. The doctoral research focused on the isolation, identifcation, semi-synthetic of the active compound as antibacterial.

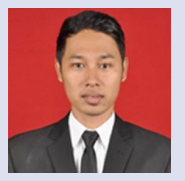

Arif Lukman: A Bachelor of Pharmacy at Faculty of Pharmacy, Mulawarman University, Samarinda, East Kalimantan, Indonesia. He has an interest in the antimicrobial activity of herbal plants.

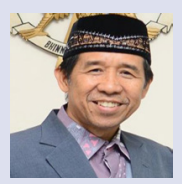

Dr. Muhammad Amir Masruhim: A Professor at Department of Chemistry Education and as a Dean at Faculty of Teacher Training and Education Sciences, Mulawarman University, Samarinda, East Kalimantan, Indonesia.

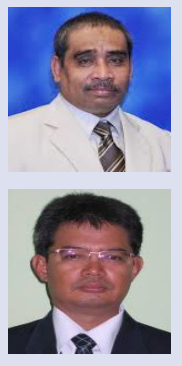

Dr. Laode Rijai: Associate Professor and Dean at Faculty of Pharmacy, Mulawarman University, Samarinda, East Kalimantan, Indonesia. He has experience in the area of Natural Product and Organic Chemistry.

Dr. Abdul Mun'im: Associate Professor at Department of Pharmaceutical Sciences, Faculty of Pharmacy, Universitas Indonesia, Depok, West Java, Indonesia. He has experience in the area of Pharmacognosy and Phytochemistry, working in drugs discovery of herbal plants, extraction engineering, Metabolite profiling, Structure Elucidation, and Degenerative Diseases (such as diabetes mellitus, antihypertension, and cholesterol).

Cite this article: Ahmad I, Ambarwati NSS, Lukman A, Masruhim MA, Rijai L, Mun'im A. In vitro Antimicrobial Activity Evaluation of Mangrove Fruit (Sonneratia caseolaris L.) Extract. Pharmacog J. 2018;10(3):598-601. 